Open Access

\title{
Modulation of HIV Binding to Epithelial Cells and HIV Transfer from Immature Dendritic Cells to CD4 T Lymphocytes by Human Lactoferrin and its Major Exposed LF-33 Peptide
}

\author{
Laetitia Carthagena $^{1, \Theta, \S}$, Pierre Becquart ${ }^{1,2,}$, Hakim Hocini ${ }^{3}$, Michel D Kazatchkine ${ }^{4}$, \\ Hicham Bouhlal ${ }^{1,5}$ and Laurent Belec ${ }^{*}, 1,4$ \\ ${ }^{1}$ Inserm U743/Team «Immunité et Biothérapie Muqueuse », Paris, France \\ ${ }^{2}$ MIVEGEC (IRD 224 - CNRS 5290 - Universités Montpellier 1\&2), Institut de Recherche pour le Développement \& \\ Centre National pour la Recherche Scientifique \& Université Montpellier I, Montpellier, France \\ ${ }^{3}$ Institut National de la Santé et de la Recherche Médicale UMR-S 945, France \\ ${ }^{4}$ Hôpital Européen Georges Pompidou, Paris, and Université Paris Descartes, Paris V, France \\ ${ }^{5}$ Université Jules Verne Picardie, Inserm U925, Faculté de Médecine, Amiens, France \\ ${ }^{\circ}$ Current address: Unité Inserm 996 - Cytokines, Chimiokines et immunopathologie, 92140 Clamart Cedex, France
}

\begin{abstract}
Lactoferrin (LF), a multifunctional molecule present in human secretions, has potent inhibitory activities against human immunodeficiency virus (HIV). The aim of the study was to evaluate whether human LF (hLF) and its exposed domain LF-33 represented by the peptide (LF-33-GRRRRSVQWCAVSQPEATKCFQWQRNMRKVRGP) involved in LF-HIV gag binding and endotoxines neutralization, may inhibit early steps of HIV mucosal transmission. Human LF and the peptide LF-33 inhibited the attachment of primary X4-tropic HIV-1 $1_{\mathrm{NDK}}$ and R5-tropic HIV-1 $1_{\mathrm{JR}-\mathrm{CSF}}$ strains to human endometrial (HEC-1) and colorectal (HT-29) CD4-negative epithelial cells, the purified hLF being more potent (up to $80 \%$ ) than the LF-33 peptide. In addition, the hLF, but not the LF-33 peptide, inhibited up to $40 \%$ the transfer in trans of HIV-1 $1_{\mathrm{JR}-\mathrm{CSF}}$ and HIV-1 $1_{\mathrm{NDK}}$, from immature dendritic cells to CD4 T lymphocytes, likely in a DCSIGN-dependent manner. Altogether, these findings demonstrate that hLF can interfere with HIV-1 mucosal transmission by blocking virus attachment to epithelial cells and by inhibiting virus transfer from dendritic cells to CD4 T cells, two crucial steps of HIV dissemination from mucosae to lymphoid tissue.
\end{abstract}

Keywords: Lactoferrin, HIV-1, mucosal transmission.

\section{INTRODUCTION}

Lactoferrin (LF) is a major iron-binding protein of innate immunity against microbial infections, abundantly present in mucosal secretions [1]. An exposed site containing 33 residues (LF-33-GRRRRSVQWCAVSQPEATKCFQWQR NMRKVRGP) constitutes the glycosaminoglycans recognizing site of the human LF (hLF), whose first six Nterminus residues are critical for its anti-endotoxin activity [2]. Human LF has also been shown to exhibit potent antiviral activity in vitro against a wide range of viruses, including human immunodeficiency virus type 1 (HIV-1) [35]. The inhibitory activities of hLF against HIV-1 take place in early steps of infection, probably during adsorption of the virus to target cells [6]. The presence of two mutations in HIV-1 env gene in bovine LF-resistant HIV-1 variants further suggests that LF targets the HIV-1 entry process [7].

\footnotetext{
*Address correspondence to this author at the Hôpital Européen Georges Pompidou, and Université Paris Descartes (Paris V), 15-20 rue Leblanc, 75908 Paris Cedex 15, France; E-mail: laurent.belec@egp.aphp.fr
}

${ }^{\S}$ Laetitia Carthagena and Pierre Becquart contributed equally to the work
Following sexual transmission, epithelial cells, immature dendritic cells (iDC) present in the mucosa tissue, together with CD4 T lymphocytes, are the first cells to encounter the virus [8]. Infectious HIV-1 particles that are not sequestrated at apical surface of epithelial cells are captured by iDC and transported to the draining lymph nodes where the virus is efficiently transfered to CD4 T cells. In the initial phase, HIV-1 interacts with receptors expressed on iDC such as Ctype lectin receptors (CLR). The dendritic cell-specific intercellular adhesion molecule-3-grabbing non-integrin (DC-SIGN) molecule plays a crucial role in binding HIV-1 through the gp120/41 envelope and in transmitting HIV-1 to target cells [9]. Recently, we demonstrated that hLF limited specifically the adsorption of R5- and X4- tropic free HIV-1 particles on endometrial HEC-1 epithelial cells by inhibiting virus adsorption on heparin-sulfated proteoglycans [10]. Furthermore, hLF was shown to strongly bind to DC-SIGN on dendritic cells, and prevent HIV-1 capture and transmission to CD4 T cells [11]. The region of the hLF involved in these mechanisms remains still to be clarified.

The aim of the present study was to evaluate whether hLF and its exposed domain LF-33 involved in LF-HIV gag binding and endotoxines neutralization, may inhibit early steps of HIV mucosal transmission, including HIV-1 
attachment to epithelial and dendritic cells, and HIV-1 transfer from iDC to CD4 T lymphocytes.

\section{MATERIALS AND METHODOLOGY}

\subsection{Reagents and Antibodies}

The hLF purified from human breastmilk was purchased from Sigma Aldrich (St Louis, Montana, USA); the Oregon Green 488 fluorescence conjugated lactoferrin from Molecular Probes (Oregon Green 488 fluorescence, Molecular probes, Belgium); the cytokines GM-CSF, IL-4, IL-2, the fluochrome-conjugated directed against CD4, CD1a, DC-SIGN, CD86, CD83, CXCR4 and CCR5, from R\&D (R\&D system, Oxon, UK) and BD Pharmingen (Le pont de Claix, France); the goat anti-rabbit-FITC from Jackson Immunoresearch, USA. The peptide LF-33 GRRRSVQWCAVSQPEATKCFQWQRNMRKVRGP was synthesized by Sequentia (SA, Evry, France). The [342371]-DC-SIGN peptide YWNRGEPNNVGEEDCAEFSGN GWNDDKCNL, which corresponds to the carbohydrate recognition domain (CRD), was synthesized by Sigma Aldrich. Polyclonal anti-gp160 IgG were purified from a pool of sera sampled from HIV-1-infected patients (laboratoire de virologie, Hôpital Européen Georges Pompidou, Paris, France). The concentrations of hLF and LF-33 peptide in $\mu \mathrm{g} / \mathrm{ml}$ correspond to $12.8 \mathrm{nM}$ and $250 \mathrm{nM}$, respectively.

\subsection{Cells}

The human colorectal epithelial cells line HT-29, and endometrial cells HEC-1A were provided by the American Type Culture Collection, Manassas, VA (ATCC HTB-38). Cells were grown in RPMI 1640 medium complemented with $10 \%$ fetal calf serum (FCS), penicillin $(100 \mathrm{IU} / \mathrm{ml})$ and streptomycin $(100 \mu \mathrm{g} / \mathrm{ml})$. The HT-29 cells were CD4- DC$\mathrm{SIGN}^{-}, \mathrm{CXCR} 4^{\text {hight }}$, $\mathrm{CCR}^{\text {low }}{ }^{\text {t }}$ and $\mathrm{GalCer}{ }^{\text {hight }}$, and the HEC-

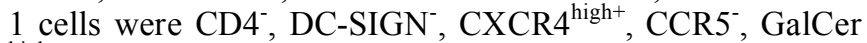

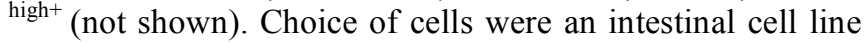
(HT-29) and an endometrial cell line (HEC-1), corresponding to two mucosal tissue largely involved in HIV acquisition in exposed people (intestinal and genital mucosae).

Peripheral blood mononuclear cells (PBMC) were isolated from cytapheresis of healthy adult donors by Ficoll density gradient centrifugation on medium for separate of lymphocytes (Eurobio, Courtaboeuf, France). Purification of monocytes was performed using the so-called "roseting" technic. In brief, PBMC $\left(10^{7} / \mathrm{ml}\right)$ were incubated for $20 \mathrm{~min}$ in ice with sheep erythrocytes treated with 2-aminoethylisothiouronium bromide (AET) ( $\mathrm{vol} / \mathrm{vol})$, and subjected to a second Ficoll centrifugation. The iDC were obtained by culturing monocytes $\left(10^{6} / \mathrm{ml}\right)$ in RPMI 1640 in heatinactivated human serum $(10 \%)$ in plastic culture plates for 1 $\mathrm{h}$ at $37^{\circ} \mathrm{C}$. After washing, mononuclear adherent cells were cultured for 6 days in RPMI 1640 containing 10\% FCS, penicillin $(100 \mathrm{IU} / \mathrm{ml})$, streptomycin $(100 \mu \mathrm{g} / \mathrm{ml})$, and IL4/GM-CSF (R\&D Systems Europe, Abingdon, Oxon, UK) both at $10 \mathrm{ng} / \mathrm{ml}$ by changing medium every $48 \mathrm{~h}$. Autologous lymphocytes (PBL) were obtained from the pellet of the second Ficoll centrifugation after lysis of sheep erythrocytes $\left(5 \mathrm{~min} \mathrm{NH}_{4} \mathrm{Cl}\right.$ ). After washing, PBL were cultured in the presence of IL-2 $(10 \mathrm{ng} / \mathrm{ml})$ and phytohemaglutinin (PHA; $2.5 \mu \mathrm{g} / \mathrm{ml}$ ) for $48 \mathrm{~h}$ at $37^{\circ} \mathrm{C}, 5 \%$
$\mathrm{CO}_{2}$. After washing, an additional culture was carried out for $24 \mathrm{~h}$ in the presence of IL-2 $(10 \mathrm{ng} / \mathrm{ml})$. The purity of iDC and $\mathrm{T}$ cells was assessed by morphological criteria and flow cytometry analysis (iDC: $90 \%$ or more pure; CD4 T cells: $85 \%$ or more pure).

\subsection{Viral Strains}

Primary X4-tropic strain HIV-1 $1_{\mathrm{NDK}}$ and R5-tropic strain HIV-1 $1_{\text {JR-CSF }}$ were a gift of Prof. F. Barré-Sinoussi (Institut Pasteur, Paris, France). The HIV-1 $1_{\mathrm{NDK}}$ viral stock was obtained by growing virus in IL-2-activated lymphocytes of healthy donors. The R5-tropic HIV-1 $1_{\mathrm{BaL}}$ and HIV-1 $1_{\mathrm{JR}-\mathrm{CSF}}$ were amplified in monocyte-derived macrophages cultures. Primary strains are thought to be representative of viral strains not adapted to their microcellular environment. In addition, both monocytotropic (R5-tropic) and lymphocytotropic (X4-tropic) HIV-1 strains are present in genital secretions, and may participate to HIV mucosal crossing in an exposed receptive individual.

\subsection{Flow Cytometry Assessment of hLF Binding to Epithelial and Dendritic Cells}

The constitutive expression of LF by epithelial cells used in all experiments and the binding of exogenous hLF were analysed by flow cytometry. Briefly, iDC, HEC-1 and HT29 cells $\left(10^{6}\right.$ cells $)$ were incubated with polyclonal antibody to $\mathrm{LF}$ for $30 \mathrm{~min}$ at $4^{\circ} \mathrm{C}$, and the expression of LF was assessed after fixation of cells with $1 \%$ paraformaldehyde (PFA), by FACSCalibur ${ }^{\mathrm{TM}}$ and the CELL QUEST ${ }^{\mathrm{TM}}$ software (Becton Dickinson, New Jersey, USA). To analyse the binding of hLF and LF-33 peptide to epithelial cells and iDC, $10^{6}$ cells were incubated with the Oregon Green 488 fluorescence conjugated LF at 10 and $30 \mu \mathrm{g} / \mathrm{ml}$ for $1 \mathrm{~h}$ in ice. Cells were fixed with $1 \%$ PFA, and subjected to flow cytometry. In order to evaluate possible involvement of the LF-33 peptide in the attachment of hLF in some experiments, cells were pre-incubated with LF-33 peptide at $20 \mu \mathrm{g} / \mathrm{ml}$ before addition of stained hLF.

\subsection{Modulation of HIV Attachment to Epithelial Cells by hLF and LF-33 Peptide}

To investigate the effect of LF-33 peptide and hLF on attachment of HIV-1 particles to epithelial cells, epithelial HT-29 and HEC- 1 cells $\left(10^{6}\right.$ cells/well $)$ were incubated with various quantities of LF-33 peptide or hLF for $30 \mathrm{~min}$ at room temperature. Afterwards, viral particles from $\mathrm{HIV}-1_{\mathrm{BaL}}$, HIV- $1_{\text {JR-CSF }}$ and HIV- $1_{\text {NDK }}$ strains (5 ng of p24 antigen) were added on epithelial cells, for $1 \mathrm{~h}$ at $37^{\circ} \mathrm{C}$. After intensive washings (5-fold) with RPMI 1640, cells were lysed by addition of $1 \%$ Triton in PBS during $15 \mathrm{~min}$ at $37^{\circ} \mathrm{C}$. Cell lysates were centrifuged, and the HIV-1 p24 antigen concentration was measured in the supernatant fractions by means of immunocapture enzyme-linked immunosorbent assay (HIV-1 core profile ELISA, DuPont de Nemours, Les Ulis, France).

\subsection{Binding of hLF and LF-33 to DC-SIGN}

The interactions between the HIV-1 glycoprotein gp160, the DC-SIGN and the hLF or LF-33 peptide were analysed by ELISA. Briefly, a synthetic [342-371]-DC-SIGN peptide YWNRGEPNNVGEEDCAEFSGNGWNDDKCNL, corresponding to the CRD domain including the gp120 binding site, 
was adsorbed on plastic plate $(10 \mu \mathrm{g} / \mathrm{ml})$ for $18 \mathrm{~h}$ at $4{ }^{\circ} \mathrm{C}$. The wells were then satured with PBS/skimmed milk (1\%) for 2 $\mathrm{h}$ at $37^{\circ} \mathrm{C}$. After washing, the DC-SIGN peptide was incubated with hLF $(100 \mu \mathrm{g} / \mathrm{ml})$ for $18 \mathrm{~h}$ at $4^{\circ} \mathrm{C}$. The fixed LF was detected using hLF-specific antibodies coupled to peroxydase $(1 \mu \mathrm{g} / \mathrm{ml})$ and streptavidin $(1 / 100$, Perkin Elmer, Boston, USA). The optical density was meseared at $590 \mathrm{~nm}$ before ortho-phenylene diamine (OPD) (Pierce, Rockforf, USA) addition.

\subsection{Inhibition Experiments of HIV Attachment and Transfer by hLF and LF-33}

The immature phenotype of dendritic cells was checked before each experiment by flow cytometry for their expression of CD1a, CD83 and CD86, and of HIV-1 receptors and co-receptors (CD4, CCR5, CXCR4 and DCSIGN), using FITC-conjugated anti-CCR5 and CD83 and PE-conjugated anti-CD4, CXCR4, DC-SIGN, CD1a and CD86 antibodies, for $30 \mathrm{~min}$ at $4^{\circ} \mathrm{C}$. Cells $\left(10^{5}\right.$ cells $\left./ \mathrm{ml}\right)$ were washed in PBS/BSA $(0.5 \%)$ and fixed in PFA $(1 \%)$ before FACSCalibur ${ }^{\mathrm{TM}}$ and the CELL QUEST ${ }^{\mathrm{TM}}$ software analyses.

Immature dendritic cells $\left(10^{5}\right.$ cells per essay) were incubated with primary R5-tropic HIV-1 $1_{\mathrm{JR}-\mathrm{CSF}}$ and with X4tropic HIV-1 $1_{\text {NDK }}(1 \mathrm{ng} / \mathrm{ml}$ of p24 antigen $)$ for $1 \mathrm{~h}$ at $37^{\circ} \mathrm{C}$. For inhibition experiments, cells were incubated with 30 and $100 \mu \mathrm{g}$ of $\mathrm{hLF}$ and LF-33, respectively, before virus addition. Cells were then extensively washed, and the p24 antigen was measured by ELISA after Triton treatment of supernatants.

Inhibition of HIV-1 transfer in trans to CD4 T lymphocytes by hLF and LF-33 peptide was investigated by incubation of cells with hLF and LF-33 before addition of virus. Cells were then washed, and IL-2- and PHA- activated autologous CD4 T lymphocytes $\left(5 \times 10^{6}\right.$ cells $)$ were added, and the p24 antigen was measured at 3 days of co-culture.
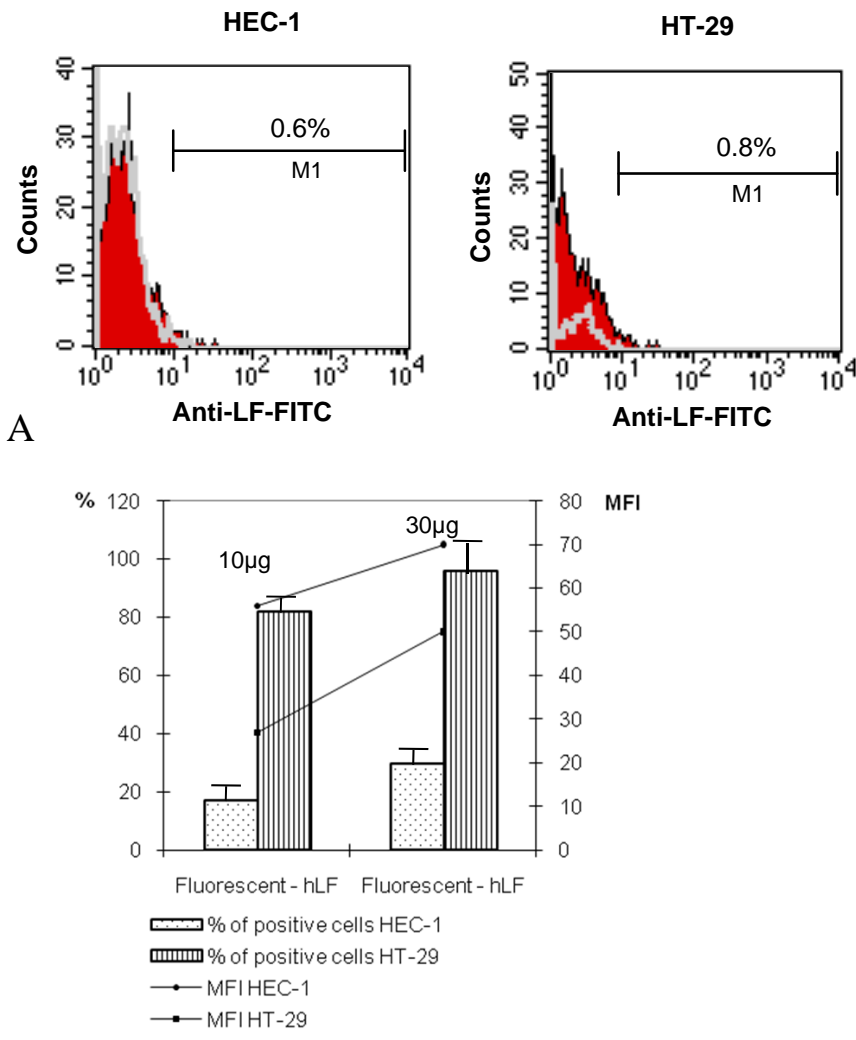

C

Fig. (1). Binding of hLF to epithelial HEC-1 and HT-29 cells. (A): Lack of constitutive expression of LF at cellular surface of epithelial cells. Cells were incubated with anti-lactoferrin for $30 \mathrm{~min}$ at $4{ }^{\circ} \mathrm{C}$, washed and incubated with Oregon-fluorescent-conjugated anti-rabbit for additional $30 \mathrm{~min}$ at $4^{\circ} \mathrm{C}$. Cells were then fixed by PFA (1\%) and analysed by FACScalibur analysis. One representative of 4 ruled out independent experiments is shown. (B): Human LF binds to HEC-1 and HT-29. Epithelial cells were incubated with fluorescent hLF at 10 and $30 \mu \mathrm{g}$ (e.g. 128 and $384 \mathrm{nM}$ ) for $1 \mathrm{~h}$ at $4{ }^{\circ} \mathrm{C}$, fixed and analysed by FACScalibur. The corresponding percentages of positive cells and mean fluorescences are mentioned in the correspond quadrant. Data are from a typical experiment representative of four independent experiments. (C): The mean \pm SD of LF positive cells and corresponding mean MFI calculated from 4 experiments is presented. 


\subsection{Statistical Analyses}

The non parametric Wilcoxon signed-rank and Friedman's tests were used for statistical analyses.

\section{RESULTS}

\subsection{Inhibition of HIV-1 Attachment to Epithelial Cells by hLF and LF-33 Peptide}

We investigated whether hLF and LF-33 peptide were capable to inhibit attachment of free R5-tropic HIV-1 $1_{\mathrm{BaL}}$ and HIV- $1_{\text {JR-CSF, }}$, and X4-tropic HIV-1 $1_{\mathrm{NDK}}$ strains to HT-29 and HEC-1 epithelial cells. We first determined the LF baseline expression by epithelial cells. A neglected percent of epithelial cells expressed hLF, 0.6 and $0.8 \%$, respectively (Fig. 1A).

The HT-29 and HEC-1 cells were incubated with hLF conjugated to the Oregon Green 488 fluorochrome $(10 \mu \mathrm{g}$ and $30 \mu \mathrm{g}$ ), fixed and analysed by flow cytometry. The hLF binding to HEC-1 cells was at $17 \%$ (MFI 56) and 30\% (MFI 70) when used at $10 \mu \mathrm{g}$ and $30 \mu \mathrm{g}$, respectively. The hLF binding to the HT-29 cells was at $82 \%$ (MFI 27) and at $96 \%$ (MFI 50) when used at $10 \mu \mathrm{g}$ and $30 \mu \mathrm{g} / \mathrm{ml}$, respectively (Fig. 1B, C).

In order to evaluate whether the exposed LF-33 domain may be involved in hLF attachment to cells, competition experiments between fluorescent hLF and unconjugatedfluorochrome (used as control) or LF-33 peptide were carried out. The epithelial cells were pre-incubated with LF33 peptide (or the cold lactoferrin), then washed and incubated with the fluorescent hLF. Attachment of hLF was determined by flow cytometry. Results of these experiments were analysed at two levels, according to the affinity of LF binding on epithelial cells. Thus, M1 gate allowed to estimate all cells binding hLF, while M2 gate was specific of the cells binding hLF with high affinity (stronger signal) (Fig. 2). M1 and M2 gates were defined function of the fluorescent hLF alone control dot. As expected, a decrease of conjugated hLF attachment was observed when cells were pre-incubated with cold LF (Fig. 2). Interestingly, the competition with LF-33 peptide experiment revealed an inhibition of hLF binding on HEC-1 and HT-29. Indeed, preincubation of the peptide was associated with a decreased total hLF binding, from $50 \%$ to $40 \%$ on HEC-1 cells, and from $43 \%$ to $17 \%$ on HT-29 cells (Fig. 2). The competitor effect of LF-33 peptide were mainly observed on cell binding hLf with high affinity (Gate M2), since there was decrease from $10 \%$ to $3 \%$, and from $33 \%$ to $4 \%$ of the LF binding on HEC-1 and HT-29, respectively. Moreover, LF33 peptide inhibited more efficiently the hLF binding on HT29 than HEC-1 (Fig. 2). These results indicate that the LF-33 peptide binds on epithelial cells with a high affinity, and also on hLF cell membrane receptors.

We further investigated whether hLF and LF-33 peptide were able to inhibit the attachment of free R5-tropic HIV$1_{\text {JR-CSF }}$ and X4-tropic HIV-1 $1_{\text {NDK }}$ particles to HT-29 and HEC1 epithelial cells. Cells were incubated with viruses in the presence of hLF and LF-33 peptide for $1 \mathrm{~h}$ at $37^{\circ} \mathrm{C}$. Under these experimental conditions, we assume that internalisation of HIV particles via alternative receptor in CD4-negative epithelial cells can be considered as negligible. Cells were then washed and HIV-1 p24 antigen was measured. Pre-
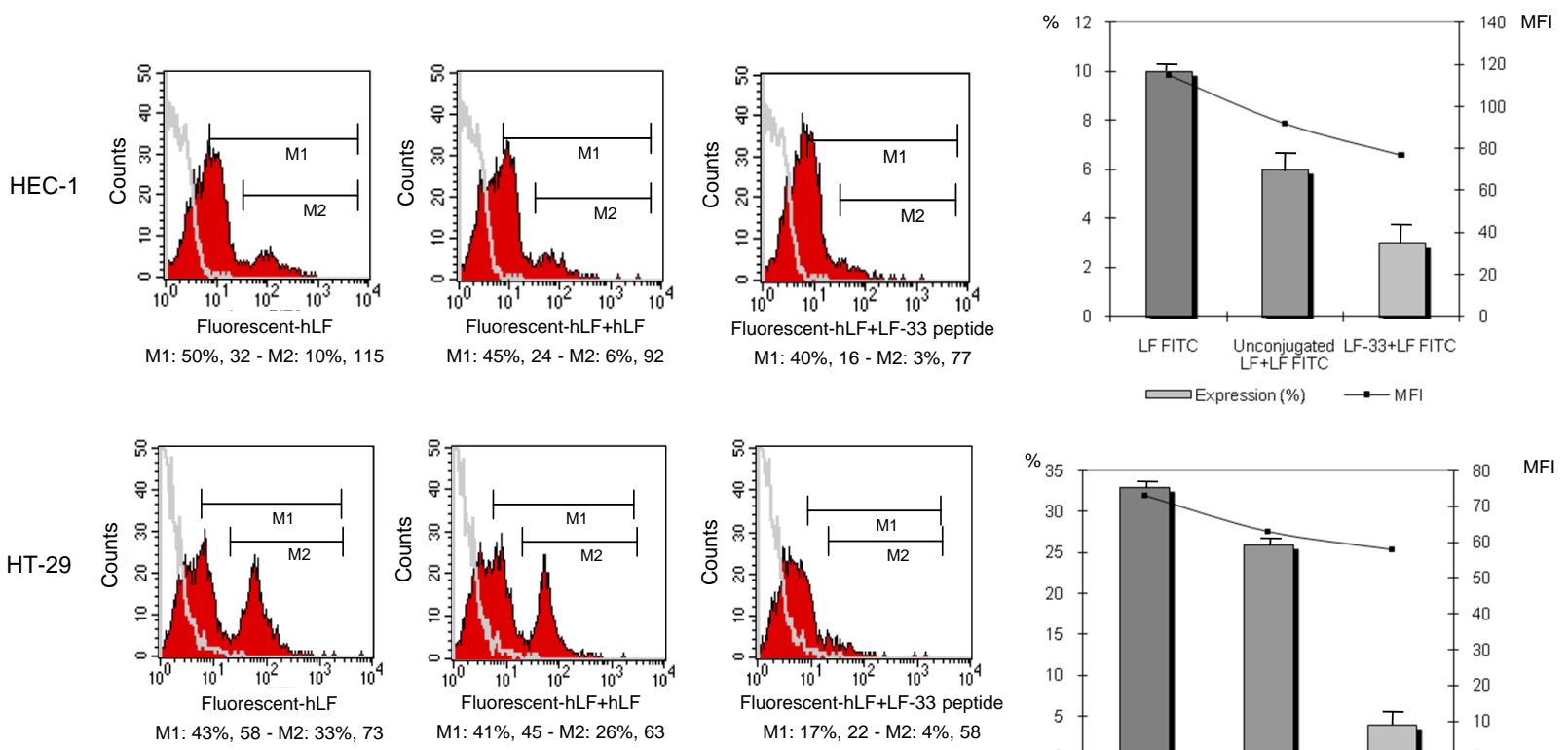

Fig. (2). Competition of hLF binding to epithelial cells by the LF-33 peptide. HEC-1 and HT-29 cells were incubated with hLF (20 $\mu \mathrm{g}$ or $256 \mathrm{nM})$ or LF-33 peptide $(20 \mu \mathrm{g}$ or $5 \mu \mathrm{M})$ for $30 \mathrm{~min}$ at $4{ }^{\circ} \mathrm{C}$, washed to eliminate the hLF and peptide excess before to be incubated with fluorescent-hLF $(20 \mu \mathrm{g})$ for $1 \mathrm{~h}$ at $4^{\circ} \mathrm{C}$ and analysed by flow cytometry. Histograms depict the mean $\pm \mathrm{SD}$ of binding (\%) and mean fluorescences calculated on M2 gate obtained from 3 independent experiments. 


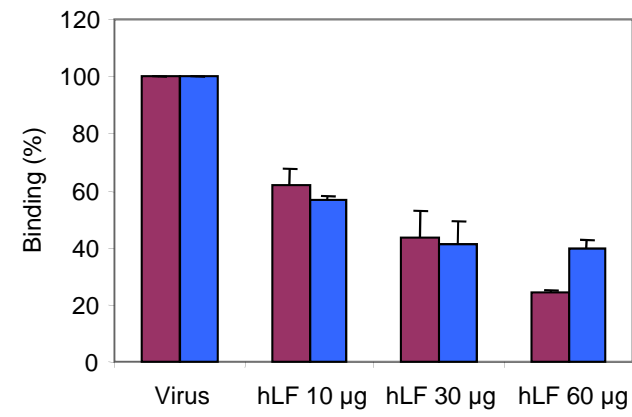

HEC-1

A

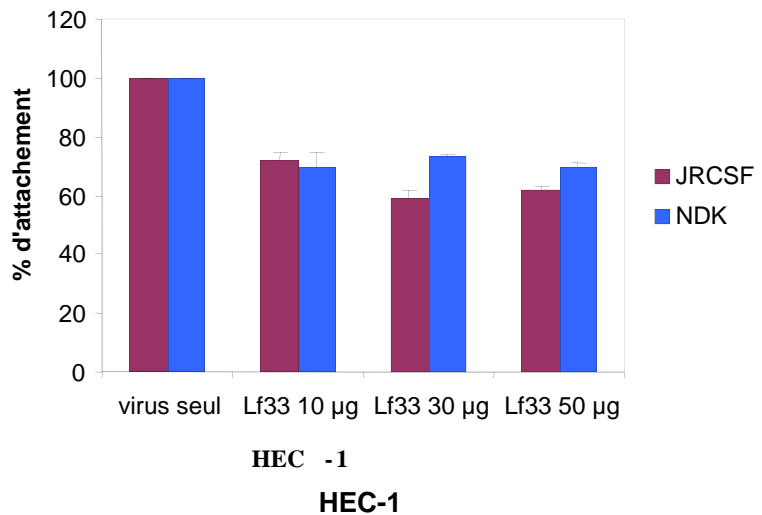

C

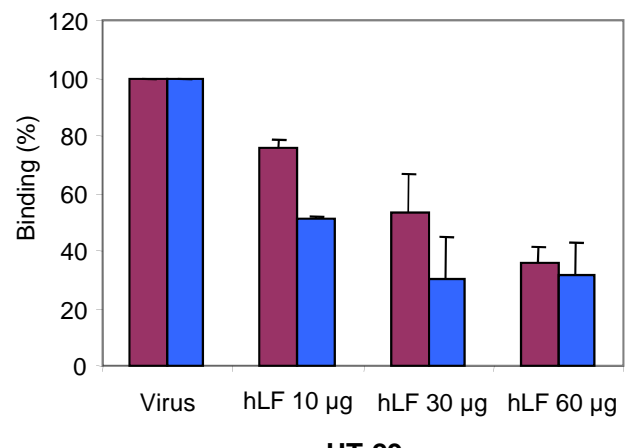

HT-29

B

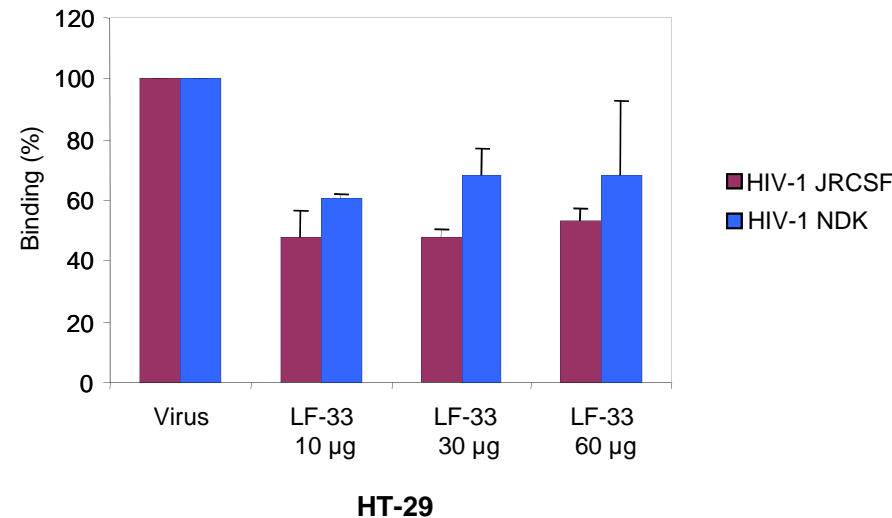

$\mathrm{D}$

Fig. (3). Binding inhibition of HIV-1 to epithelial cells by hLF and LF-33 peptide. HEC-1 (A and C) and HT-29 (B and D) cells (10 ${ }^{6}$ cells) were incubated with $\mathrm{HIV}-1_{\mathrm{JR}-\mathrm{CSF}}$ and $\mathrm{HIV}-1_{\mathrm{NDK}}$ particles $(5 \mathrm{ng} / \mathrm{ml}$ of $\mathrm{p} 24$ antigen $)$ for $1 \mathrm{~h}$ at $37^{\circ} \mathrm{C}$. After washes, adsorbed virus was treated by Triton and p24 antigen was measured by ELISA. Cells were pre-incubated with hLF (A and B), LF-33 peptide (C and D) or an irrelevant peptide control (not shown) for $30 \mathrm{~min}$ at room temperature before virus addition. Results are represented as percentage of the control (performed without pre-incubation of cells with hLF or LF-33 peptide), and corresponds to the mean \pm SD from 3 independent experiments. In experimentations, $10 \mu \mathrm{g} / \mathrm{ml}$ of hLF and LF-33 peptide corresponded to $128 \mathrm{nM}$ and $2.5 \mu \mathrm{M}$, respectively.

incubation of cells with human LF at $10 \mu \mathrm{g}, 30 \mu \mathrm{g}$ and 60 $\mu \mathrm{g}$, leads to a decrease of $38 \%, 56 \%$ and $76 \%$ of the attachment of HIV-1 $1_{\text {JR-CSF }}$ (non parametric Friedman's test for three paired groups; $\mathrm{p}<0.01)$ and of $43 \%, 58 \%$ and $60 \%$ of the attachment of HIV-1 $1_{\mathrm{NDK}}(\mathrm{p}<0.03)$, on HEC-1 cells (Fig. 3A), respectively; and of $24 \%, 47 \%$ and $64 \%$ of the attachment of HIV-1 $1_{\text {JR-CSF }}(\mathrm{p}<0.01)$, and of $49 \%, 70 \%$ and $68 \%$ of the attachment of HIV $-1_{\mathrm{NDK}}(\mathrm{p}<0.02)$, on HT-29 cells (Fig. 3B). Irrelevant peptide control used instead LF-33 showed not effect on virus attachment (not shown).

The LF-33 peptide exhibited a lower inhibitory effect on HIV-1 attachment to epithelial cells as compared to hLF. Indeed, the observed reductions of HIV-1 $1_{\text {JR-CSF }}$ binding on HEC-1 cells at $10 \mu \mathrm{g}, 30 \mu \mathrm{g}$ and $60 \mu \mathrm{g}$ of LF-33 peptide were $28 \%, 41 \%$ and $38 \%(\mathrm{p}<0.04)$, respectively, and those of $\mathrm{HIV}-1_{\mathrm{NDK}}$ bound on HEC-1 cells were $30 \%, 27 \%$ and $30 \%(\mathrm{p}<0.05)$, respectively (Fig. 3C). The decreases of HIV$1_{\text {JR-CSF }}$ attachment to HT-29 cells at $10 \mu \mathrm{g}, 30 \mu \mathrm{g}$ and $60 \mu \mathrm{g}$ of LF-33 peptide were of $52 \%, 52 \%$ and $47 \% \quad(p<0.04)$, respectively, and those of $\mathrm{HIV}-1_{\mathrm{NDK}}$ attachment on $\mathrm{HEC}-1$ cells were $39 \%, 32 \%$ and $31 \%(\mathrm{p}<0.05)$, respectively (Fig. 3D).

\subsection{Inhibition of HIV-1 Transfer from iDC to T Cells by hLF, but Not by LF-33 Peptide}

The dendritic cells used in all experiments presented an immature phenotype as demonstrated by the low expression of CD83 and the high expression of CD86 and CD1a; the iDC expressed also CD4 (70\%), CXCR4 (22\%), CCR5 $(10 \%)$ and DC-SIGN at $85 \%$ (Fig. 4). The incubation of iDC with hLF and LF-33 had no effect on the immature phenotype (data not shown). The Oregon-conjugated hLF used at $10 \mu \mathrm{g}$ and $30 \mu \mathrm{g}$ linked, in a dose-dependent manner, to iDC at 21 and $32 \%$, respectively (Fig. 5A).

The effect of hLF and LF-33 on the transfer of HIV-1 from iDC to autologous CD4 T lymphocytes was further investigated. Dendritic cells were incubated with HIV-1 and hLF or LF-33 peptide before washing and addition of IL2- 

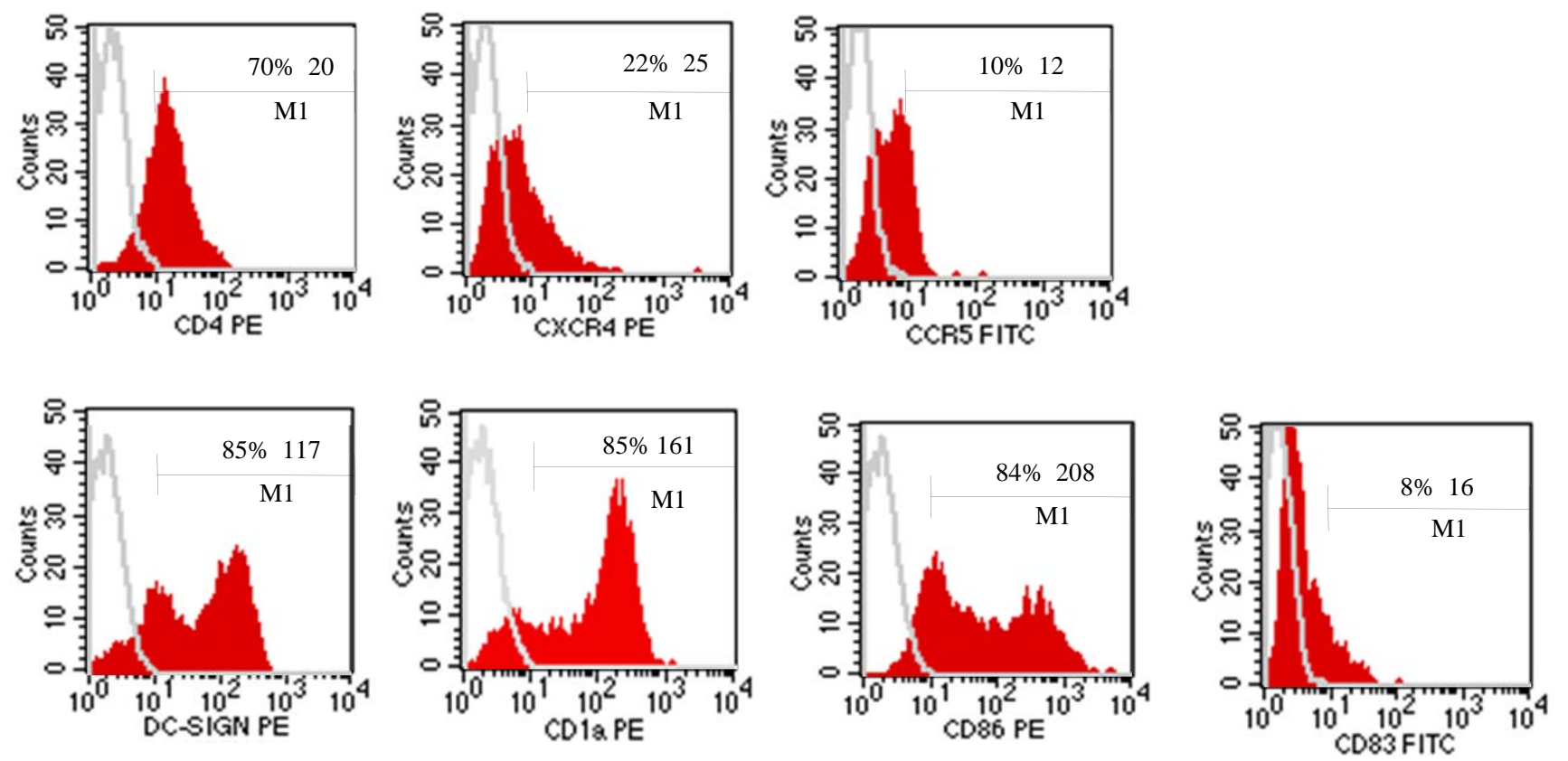

Fig. (4). Phenotypic characterization of iDC by flow cytométrie. Six days old cultured iDC were incubated with FITC/PE-conjugated antibodies or matched isotypes for $30 \mathrm{~min}$ at $4{ }^{\circ} \mathrm{C}$ before PFA $1 \%$ fixation and FACScalibur analysis. Data are from a typical experiment representative of 4 independent experiments.

activated T lymphocytes (1/5 ratio). Measurement of HIV-1 p24 antigen released at $72 \mathrm{~h}$ in the co-culture supernatant showed that at $30 \mu \mathrm{g}$ and $100 \mu \mathrm{g}$, the percentages of HIV$1_{\text {JR-CSF }}$ transfer by hLF were decreased by $56 \%$ and $61 \%$ (non parametric Wilcoxon signed-rank; $\mathrm{p}<0.01$ ), respectively (Fig. 5B); and those of HIV- $1_{\mathrm{NDK}}$ transfer were $44 \%$ and $64 \%(p<0.01)$, respectively (Fig. 5B). No inhibitory effect was observed when the LF-33 peptide was used. Unexpectedly, the incubation with the LF-33 peptide enhanced 3 to 6 fold the HIV-1 transfer from iDC to autologous CD4 T cells ( $p<0.01$ for HIV- $1_{\text {JR-CSF }}$ and $p<0.02$ for HIV-1 $1_{\mathrm{NDK}}$ ), as shown in Fig. (5D), likely because the peptide increased the HIV-1 attachment to iDC ( $<<0.02$ for HIV- $1_{\text {JR-CSF }}$ and $p<0.03$ for HIV- $1_{\text {NDK }}$ ), as demonstrated by binding inhibition experiments (Fig. 5C). Irrelevant peptide control used instead LF-33 showed not effect on virus attachment to iDC nor on virus transfer from iDC to $\mathrm{T}$ cells (not shown).

Finally, the interactions between hLF and DC-SIGN molecule were assessed by indirect ELISA using for coating the synthetic peptide «DC-SIGN 342-371» corresponding to CRD domain of DC-SIGN interacting with HIV-1 gp120. The ELISA optical densities were 1.36 in the presence of DC-SIGN peptide, and only 0.03 in its absence (Fig. 5E), demonstrating that hLF binds to the DC-SIGN peptide.

\section{DISCUSSION}

In the present study, purified hLF inhibited the attachment of free HIV-1 to epithelial cells. Indeed, hLF inhibited as much as $90 \%$ of the attachment of X4- and R5tropic primary HIV-1 to human endometrial HEC-1 and colorectal epithelial HT29 cell lines. In addition, the effect of hLF on viral attachment on epithelial cells is likely mediated by the exposed domain LF-33. Indeed, the peptide LF-33 also inhibited significantly the attachment of primary X4and R5- tropic HIV-1 to HEC-1 and HT-29 epithelial cells. Taken together, these findings demonstrate that the inhibitory effect of hLF on HIV attachment on epithelial cells previously reported by Saïdi and colleagues [10] is associated with the external domain LF-33 peptide.

We further evaluated the ability of hLF to inhibit the transfer in trans of HIV-1 from iDC to CD4 T lymphocytes, which constitute one of the major steps of the rapid dissemination of HIV-1 from mucosa to lymphoid tissues [12]. In our hands, purified hLF inhibited up to $60 \%$ the virus transfer to $\mathrm{CD} 4 \mathrm{~T}$ lymphocytes, whereas no inhibitory effect could be observed when using the LF-33 peptide. By comparison, the most neutralizing monoclonal antibody to gp120, IgGb12, induced up to $90 \%$ HIV-1 inhibition [13]. By contrast to hLF, the LF-33 peptide enhanced HIV-1 transfer from iDC to autologous CD4 T cells. These results suggest that the LF-33 exposed domain is not involved in hLF-associated inhibition of HIV-1 transfer to CD4 T lymphocytes. Since hLF binds to DC-SIGN, one can hypothesize that hLF could block the virus transfer to lymphocytes by hampering the iDC-PBL interaction. One can also speculate that LF-33 increases HIV-1 transfer to CD4 $\mathrm{T}$ lymphocytes by enhancing the virus binding to iDC.

We showed that Oregon fluorescence-conjugated hLF was able to bind to epithelial cells in a dose-dependent manner reaching $40 \%$ of positive cells. The mechanisms by which hLF interacts with CD4-negative epithelial cells remains speculative. However, although both $\mathrm{CD} 4$ and coreceptors are essential for HIV-1 entry process, the initial association of HIV-1 particles to cells could occur in the absence of these receptors. Several observations pointed out that the attachment of HIV-1 particles to the cell surface occurs through interactions with heparan-sulfate 


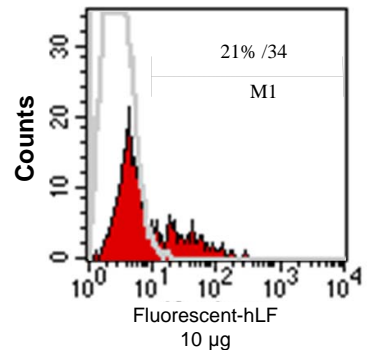

A

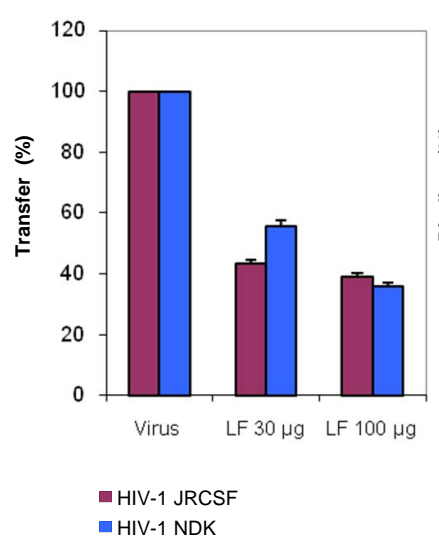

B
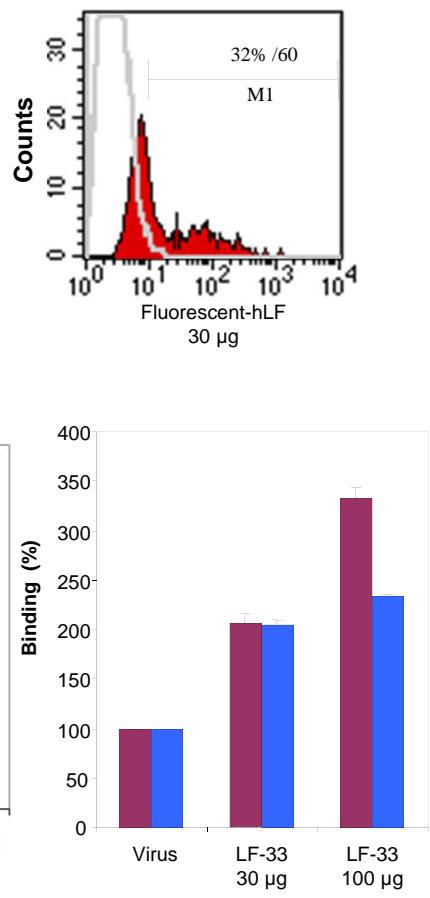

C
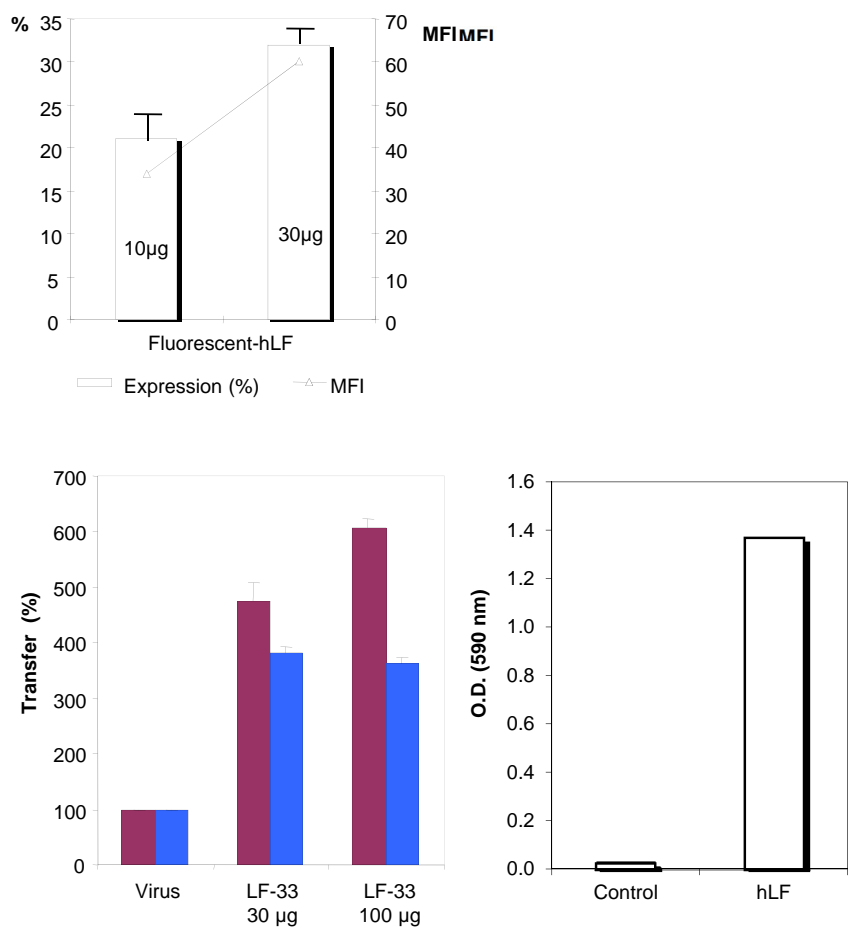

$\mathrm{D}$

Fig. (5). Inhibition of HIV-1 transfer from iDC to CD4 T lymphocytes by hLF, not LF-33 peptide. (A) hLF binding to iDC. Cells (10 cells) were incubated with Oregon-conjugated hLF (10 and $30 \mu \mathrm{g}, e . g .128$ and $384 \mathrm{nM})$ for $1 \mathrm{~h}$ at $4^{\circ} \mathrm{C}$ and analysed by FACScalibur. Data are from a typical experiment representative of four independent experiments. Histograms depict the mean \pm SD of binding (\%) and mean fluorescences obtained from 4 independent experiments. (B) Effect of hLF on HIV transfer from iDC to CD4 T lymphocytes. iDC were incubated or not with purified hLF ( 30 and $100 \mu \mathrm{g}, e . g$. 384 and $1280 \mathrm{nM}$ ) before addition of HIV-1 for $1 \mathrm{~h}$. Cells were washed and cocultured for 3 days with autologous CD4 T lymphocytes. HIV p24 antigen was measured in supernatants by ELISA at day 3. Results are represented as percentage of the control (performed without pre-incubation of cells with hLF), and is the mean of transfer \pm SD from 3 independent experiments. (C) Effect of LF-33 peptide on HIV-1 attachment to iDC. iDC were incubated with virus $(5 \mathrm{ng} / \mathrm{ml}$ of p24 antigen of HIV-1 $1_{\mathrm{JR}-\mathrm{CSF}}$ and $\left.\mathrm{HIV}-1_{\mathrm{NDK}}\right)$ for $1 \mathrm{~h}$ at $37^{\circ} \mathrm{C}$. After several washes, cells were lysed and HIV p24 antigen was measured by ELISA. Cells were pre-incubated with the LF-33 peptide at $30 \mu \mathrm{g}$ and $100 \mu \mathrm{g} / \mathrm{ml}($ e.g. $7.5 \mu \mathrm{M}$ and $25 \mu \mathrm{M})$ for $30 \mathrm{~min}$ at room temperature before virus addition. Results are represented as percentage of the control (performed without pre-incubation of cells with LF-33 peptide), and is the mean of binding \pm SD from 3 independent experiments.As negative control, an irrelevant peptide was used instead LF-33 (not shown). (D) Effect of LF-33 peptide on HIV transfer from iDC to T cells. iDC were incubated with virus $\left(5 \mathrm{ng} / \mathrm{ml}\right.$ of p 24 antigen of HIV- $1_{\text {JR-CSF }}$ and HIV$\left.1_{\mathrm{NDK}}\right)$ for $1 \mathrm{~h}$ at $37^{\circ} \mathrm{C}$. After several washes, IL-2-stimulated T cells were added to iDC and co-cultured for $72 \mathrm{~h}$ before p24 antigen measurement.As assessed by binding inhibition experiment, iDC were pre-incubated with the LF-33 peptide at $30 \mu \mathrm{g}$ and $100 \mu \mathrm{g} / \mathrm{ml}($ e.g. 7.5 $\mu \mathrm{M}$ and $25 \mu \mathrm{M}$ ) for $30 \mathrm{~min}$ at room temperature before virus addition. Results are represented as percentage of the control (performed without pre-incubation of cells with LF-33 peptide), and is the mean of transfer \pm SD from 3 independent experiments. As negative control, an irrelevant peptide was used instead LF-33 (not shown). (E) Binding of LF to DC-SIGN. DC-SIGN "342-371" peptide was adsorbed (10 $\mu \mathrm{g} / \mathrm{ml}$ ) overnight at $4^{\circ} \mathrm{C}$. Wells of ELISA plate were satured using PBS $/ 1 \%$ powder milk for $2 \mathrm{~h}$ at $37^{\circ} \mathrm{C}$ before addition of purified $\mathrm{hLF}$ at $100 \mu \mathrm{g} / \mathrm{ml}$ overnight at $4^{\circ} \mathrm{C}$. The fixed hLF was detected by peroxydase-conjugated polyclonal antibody to $\mathrm{hLF}(1 \mu \mathrm{g} / \mathrm{ml})$. As a control, the same experiment was performed in parallel without DC-SIGN "342-371" peptide adsorption.

proteoglycans and with the cell surface-expressed nucleolin [14-16], suggesting their possible involvement in HIV-1 attachment inhibition on epithelial cells by hLF. Thus, LF likely could exert its effect at the level of viral adsorption or penetration, in accordance with its highest effectiveness when administered before or simultaneous with the viral inoculum, as it occurs in vivo during breastfeeding and sexual transmission of HIV-1 [6].

The role of hLF in HIV-1 mucosal transmission remains unknown. The amounts of hLF used in our study (30 and 100 $\mu \mathrm{g} / \mathrm{ml})$ were largely below physiological concentrations, suggesting that the blocking properties of hLF on HIV-1 attachment, replication or transfer in trans, could likely modulate the efficiency of HIV acquisition through mucosal routes. However, reported observations about hLF levels in saliva and breast milk from HIV-1-infected individuals remain conflicting. Thus, both increases [17-19] and decreases $[20,21]$ in LF levels were reported. Although a linear correlation between low LF serum levels in HIVinfected pregnant women and perinatal transmission of HIV1 to the neonate has been reported [22], no correlation could be found between the level of breast milk hLF in HIV- 
infected breastfeeding mothers and the transmission of virus to their children [18]. Finally, the presence of natural antibodies to hLF present in mucosal secretions may modulate the HIV-inhibitory activity of hLF [10].

\section{CONCLUSION}

1. Taken together, our observations demonstrate that hLF may interfere with HIV-1 mucosal transmission by blocking virus attachment to epithelial cells and by inhibiting virus transfer from iDC to CD4 T lymphocytes, two crucial steps of HIV dissemination from mucosae to lymphoid tissue.

2. The differential effects of the LF-33 peptide on HIV attachment and HIV transfer suggest that hLF-mediated inhibition of early steps of HIV mucosal crossing may use two different pathways.

\section{ACKNOWLEDGEMENTS}

This work was supported by Agence Nationale de Recherches sur le SIDA et les Hépatites Virales (ANRS), France.

\section{REFERENCES}

[1] Legrand D, Pierce A, Elass E, Carpentier M, Mariller C, Mazurier J. Lactoferrin structure and functions. Adv Exp Med Biol 2008; 606: 163-94.

[2] Zhang GH, Mann DM, Tsai CM. Neutralization of endotoxin in vitro and in vivo by a human lactoferrin-derived peptide. Infect Immun 1999; 67(3): 1353-8.

[3] Harmsen MC, Swart PJ, de Bethune MP, et al. Antiviral effects of plasma and milk proteins: lactoferrin shows potent activity against both human immunodeficiency virus and human cytomegalovirus replication in vitro [see comments]. J Infect Dis 1995; 172(2): 3808.

[4] Hasegawa K, Motsuchi W, Tanaka S, Dosako S. Inhibition with lactoferrin of in vitro infection with human herpes virus. Jpn J Med Sci Biol 1994; 47(2): 73-85.

[5] Ikeda M, Nozaki A, Sugiyama K, et al. Characterization of antiviral activity of lactoferrin against hepatitis $\mathrm{C}$ virus infection in human cultured cells. Virus Res 2000; 66(1): 51-63.

[6] Puddu P, Borghi P, Gessani S, Valenti P, Belardelli F, Seganti L. Antiviral effect of bovine lactoferrin saturated with metal ions on early steps of human immunodeficiency virus type 1 infection. Int $\mathrm{J}$ Biochem Cell Biol 1998; 30(9): 1055-62.

[7] Berkhout B, van Wamel JL, Beljaars L, Meijer DK, Visser S, Floris R. Characterization of the anti-HIV effects of native lactoferrin and other milk proteins and protein-derived peptides. Antiviral Res 2002; 55(2): 341-55.

[8] Kozlowski PA, Neutra MR. The role of mucosal immunity in prevention of HIV transmission. Curr Mol Med 2003; 3(3): 217-28

[9] Izquierdo-Useros N, Blanco J, Erkizia I, et al. Maturation of bloodderived dendritic cells enhances human immunodeficiency virus type 1 capture and transmission. J Virol 2007; 81(14): 7559-70.

[10] Saidi H, Eslahpazir J, Carbonneil C, et al. Differential modulation of human lactoferrin activity against both R5 and X4-HIV-1 adsorption on epithelial cells and dendritic cells by natural antibodies. J Immunol 2006; 177(8): 5540-9.

[11] Groot F, Geijtenbeek TB, Sanders RW, et al. Lactoferrin prevents dendritic cell-mediated human immunodeficiency virus type 1 transmission by blocking the DC-SIGN--gp120 interaction. J Virol 2005; 79(5): 3009-15.

[12] Moris A, Pajot A, Blanchet F, Guivel-Benhassine F, Salcedo M, Schwartz O. Dendritic cells and HIV-specific CD4+ T cells: HIV antigen presentation, T-cell activation, and viral transfer. Blood 2006; 108(5): 1643-51

[13] Binley JM, Wrin T, Korber B, et al. Comprehensive cross-clade neutralization analysis of a panel of anti-human immunodeficiency virus type 1 monoclonal antibodies. J Virol 2004; 78(23): 1323252 .

[14] Said EA, Courty J, Svab J, Delbe J, Krust B, Hovanessian AG. Pleiotrophin inhibits HIV infection by binding the cell surfaceexpressed nucleolin. FEBS J 2005; 272(18): 4646-59.

[15] Hovanessian AG. Midkine, a cytokine that inhibits HIV infection by binding to the cell surface expressed nucleolin. Cell Res 2006; 16(2): 174-81.

[16] Legrand D, Vigie K, Said EA, et al. Surface nucleolin participates in both the binding and endocytosis of lactoferrin in target cells. Eur J Biochem 2004; 271(2): 303-17.

[17] Baynes RD, Bezwoda WR. Lactoferrin and the inflammatory response. Adv Exp Med Biol 1994; 357:133-41.

[18] Becquart P, Hocini H, Levy M, Sepou A, Kazatchkine MD, Belec L. Secretory anti-human immunodeficiency virus (HIV) antibodies in colostrum and breast milk are not a major determinant of the protection of early postnatal transmission of HIV. J Infect Dis 2000; 181(2): 532-9.

[19] Mandel ID, Barr CE, Turgeon L. Longitudinal study of parotid saliva in HIV-1 infection. J Oral Pathol Med 1992; 21(5): 209-13.

[20] Defer MC, Dugas B, Picard O, Damais C. Impairment of circulating lactoferrin in HIV-1 infection. Cell Mol Biol (Noisy-legrand) 1995 ; 41(3): 417-21.

[21] Muller F, Holberg-Petersen M, Rollag H, Degre M, Brandtzaeg P, Froland SS. Nonspecific oral immunity in individuals with HIV infection. J Acquir Immune Defic Syndr 1992; 5(1): 46-51.

[22] Semba R, editor. Nutritional interventions: vitamin A and breastfeeding. IIIrd International symposium: global strategies to prevent perinatal HIV-1 transmission, Valencia 1998 